\title{
The Litmus Test of Pride: Analysing the Emergence of the Belgrade 'Ghost' Pride in the Context of EU Accession
}

Koen Slootmaeckers - City, University of London

**Accepted for Publication in East European Politics**

\begin{abstract}
The transformation of lesbian, gay, bisexual, and transgender (LGBT) rights into a 'standard for civilisation' has not been without consequences. With LGBT Pride parades becoming a symbol for Europeanness in the European Union (EU) accession process, this article asks how the litmus test character of Belgrade Pride has transformed LGBT politics in Serbia. Empirically, the analysis provides an in-depth analysis of how Serbia's EU accession process has shaped the politics of Belgrade Pride between 2001 and 2015 and vice versa. It is argued that the international symbolic usage of Pride is no innocent practice as it has foreclosed its local politicality. Indeed, whilst Belgrade Pride became politicised as a litmus test in the EU accession process, domestically it developed into an apolitical ritualised event devoid of LGBT politics.
\end{abstract}

\section{Introduction}

In recent years, Lesbian, Gay, Bisexual, and Transgender (LGBT) rights have seemingly developed into what Roth (2014) has called the "proverbial canary in the coal mine" for countries' human rights records. A process which has taken place against the broader backdrop of the globalisation of human rights discourses (Stychin 2004). According to Donnelly $(1998,21)$, human rights "represent a progressive [contemporary] expression of the important idea that international legitimacy and full membership in the international society must rest in part on standards of just, humane or civilized behaviour." With LGBT rights now incorporated within the international human rights architecture, they came to be a norm against which countries are judged (Ammaturo 2017; Kollman and Waites 2009; Paternotte and Seckinelgin 2015). Puar (2007) conceptualised this phenomenon by coining 'homonationalism,' a term which in effect captures the process or geopolitical context in which respect for LGBT rights have developed in, what English school scholars (see e.g. Bull 1977; Buzan 2014) would label, a 'standard of civilisation' used to evaluate the international 
legitimacy of a country. This process is particularly observable in the international politics of LGBT Pride parades. Consider, for example, the European Union (EU) enlargement process in which Pride events have emerged as a symbolic marker of these countries' readiness to access the EU (Ammaturo 2017; Slootmaeckers and Touquet 2016). In fact, the ability of LGBT people to carry out their right to the freedom of assembly is used as a litmus test of Europeanness. To illustrate, (former) EU Commissioner Füle (2014) called the 2014 Pride in Belgrade a "milestone in the modern history of democratic Serbia," and Member of the European Parliament (MEP) Tanja Fajon said: "The values of tolerance and diversity that will be highlighted this Sunday [during Belgrade Pride] are European, and Serbia fully belongs in Europe" (quoted in Intergroup on LGBT Rights 2014).

However, linking LGBT rights to the appealing idea of Europeanness is said to be "far from [...] a harmless operation [... with potentially] huge political and social implications" (Ammaturo 2017, 93). This being the case, the practice of using Pride as a litmus test for Europeanness cannot be taken for granted as an unalloyed good, and must thus be critically examined. Such critical examination of the political implications of international usage of LGBT rights and Pride as litmus test is the main focus of the presented analysis. Starting from observation that Pride is inherently a local orientated phenomenon - it is a tactic of domestic LGBT activists - , this article asks: how does the international symbolism of Pride shape its domestic politics?

By providing rich empirical material and an in-depth longitudinal critical analysis of the relational nature of the international and national politics of the Belgrade Pride and its consequences for the event's local politicality, the article adds to the emerging literature on LGBT and queer politics in the post-Yugoslav space (see e.g. Bilić 2016c; Rhodes-Kubiak 2015). In addition to this empirical contribution, the article has important theoretical implications for at least three fields of social inquiry. First and foremost, the research 
contributes to critical scholarship on the globalisation of LGBT rights by providing a muchneeded challenge to the presumed universality of Pride as a strategy for raising visibility. It is argued the EU's practice of what Rahman $(2014,281)$ calls 'pink-testing' has a harmful impact on local LGBT people and politics. Second, in terms of the Europeanisation of LGBT rights literature, the presented analysis challenges the widespread belief that the EU has been a force of good that improved LGBT equality in candidate countries. Doing so, the analysis also furthers the recent 'pathological turn' of the more general Europeanisation via enlargement literature (see Mendelski 2016), despite not explicitly drawing on it. It is argued that that the domestic instrumentalisation and politicisation of reforms are not only a result the EU's outcome-focussed monitoring mechanism, but also a product of the intertwining of national and international politics. It is the relational aspect of the politics encapsulated in the enlargement process that allows for the constant negotiation and reinterpretation of EU norms.

Empirically, this article analyses the history of the Belgrade Pride between 2001 and 2015, focussing on how the Pride has been transformed as part of Serbia's European integration process. These findings are based on a process-tracing analysis of the organisational process of the Belgrade Pride in relation to Serbia's European integration process as well as the meaning of Pride within Serbian LGBT politics. A total of 89 semi-structured interviews were conducted between 2012 and 2016 with a variety of actors active within the field of LGBT politics in Serbia. This data is triangulated with data obtained through document analysis, most notably the EU Progress Reports, and through participant observation at the 2015 Belgrade Pride.

The article is structured in three parts. The first part situates the research in the wider literature, followed by a brief overview of the history of the Belgrade Pride between 2001 and 2015. The last part of the article discusses how this history has contributed to a 
transformation of the Pride in which becomes devoid of domestic LGBT politics yet a political testimony of Europeanness on the international scene.

\section{Situating the Research}

The current scholarly debate on the domestic impact of the internationalisation of LGBT politics suggests that international pressure for LGBT rights can either hinder or promote LGBT rights, depending on a country's orientation. Indeed, it has been argued that in those countries resisting the homonationalist interpretation of modernity, the international politicisation of LGBT rights has caused backlashes (Weiss and Bosia 2013; Wilkinson 2014). The anti-gay propaganda laws in Russia and the so-called 'Kill the Gays Bill' in Uganda are only two examples in which the international push for LGBT rights has reduced the space for LGBT activism in the domestic arena. By contrast, it has been argued that the increased international politicisation and visibility of the LGBT norm can engender change — albeit not necessarily in a linear way — in those countries originally hostile to LGBT norms, especially when they are "embedded in international communities that champion an LGBT norm” (Ayoub 2016, 48).

The growing literature on the impact of the EU enlargement on LGBT rights largely supports this argument by showing that the EU accession process has contributed to the adoption of new laws in candidate countries (Ayoub 2016; O'Dwyer 2012; Slootmaeckers, Touquet, and Vermeersch 2016). Although generally correct, the literature is potentially too optimistic in assessing how the EU enlargement process has shaped LGBT politics for at least two reasons. First, the current state of the literature has a predominant legal focus and employs an EUcentric perspective, aligning itself with the notion that the EU enlargement is an asymmetric process in which candidate countries must (at least formally) comply with EU rules. Focussing on the top-down conceptions of Europeanisation (particularly relying on the 
impact of the conditionality principle), the EU's LGBT-friendliness is too often taken for granted with LGBT rights considered as non-negotiable conditions of EU membership (see e.g. O’Dwyer 2012). Such an approach, however, does not work for those issues which are not rooted in the EU acquis, as this article will demonstrate. In line with the work of Diez (2013), this article argues that EU's LGBT equality norms are not simply passed on to candidate countries, but their meanings are reinterpreted and negotiated through the political process that underlays EU enlargement. Thus, rather than asking what the domestic impact of the EU Enlargement process on LGBT rights is, one should ask from a transnational perspective how the process configures the international and national politics and what outcomes this produces.

A second reason why the existing literature might be too optimistic relates to its view on the international context. The previously mentioned notion that the international visibility of the LGBT norm is a 'force of good' when states seek to enter the LGBT-friendly international community might not accurately reflect reality, as the international context is not just a scoping condition but in fact actively shapes (and is shaped by) domestic LGBT politics. According to Rahman $(2014,279)$, Western sexual exceptionalism is triangulated through a homocolonialist process in which homonormative nationalism is deployed "within a dialectic of respectability/otherness in a classic colonializing mode, directed at 'traditional' ['Eastern'/non-European] cultures as homophobic non-Western 'others' that need to be civilized or modernized but also constructing 'home' Western normative queer identities." The importance of Rahman's work lies in the fact that he argues that resistance to the sexual politics of the West is very much part of the triangulation process as it accepts the configuration of Western exceptionality. As such, sexual politics are located in the relation between the EU and the candidate countries, whereby the promotion of and resistance to LGBT equality produces political outcomes both at the international and domestic level, as 
well as positions local LGBT activists in an awkward liminal position, i.e., stuck between the West-East dynamic created by the EU enlargement process. This being the case, one cannot just assume an always positive impact of international LGBT norm visibility —albeit with the recognition that visibility may initially increase hostility-, but one must analyse the EU enlargement process using a transnational approach, sensitive to its relational politics and conscious of the (potential) pathological consequences of these multiscalar LGBT politics. This is particularly the case when LGBT rights are used as a litmus test or a 'standard of civilisation,' as doing so is not a harmless operation. Indeed, the litmus test nature of Pride at the international level does not only contribute to the triangulation of Western exceptionalism, but, through the political integration process, also creates a domestic opportunity to transform the domestic politics of the event to serve the elite's interests. Indeed, as Mendelski (2016) has shown when progress is measured by outcomes rather than by processes — as is done with a litmus test —, reforms might become 'instrumentalised' and politicised by local elites to serve ulterior motives. Hence, it is argued that the EU Enlargement's homocolonialist practice of making LGBT rights, and particularly LGBT Pride, a 'standard of civilisation' or a litmus test for modernity and Europeanness produces important challenges for local LGBT activists and politics, leading to adoption of seemingly LGBT-friendly policies or actions that, whilst serving an international agenda, remain irrelevant for the advancement of LGBT equality in the domestic sphere.

Although Europeanisation via enlargement has been a dominant framework of analysis when studying candidate EU members, this article does not draw from this literature as its tends to be relatively insensitive to the politics of enlargement and focuses too much on institutions. Indeed, this strand of literature would ask how the Enlargement process contributed to the occurrence of Pride, without considering how LGBT equality norms are reinterpreted and/or transformed by the process. In order to capture the latter, this article instead draws from the 
recent work of Szulc (2018), who convincingly calls for a transnational approach to the study of LGBT politics in the former-communist regions. The multiscalar character of such an approach is indeed best suited for the purpose of this research as it does favour on level over the other, but rather takes the national and non-national as supplementary levels of analysis. Thus, rather than analysing a top-down impact of the international setting on the domestic politics, a transnational analysis highlights, as Szulc $(2018,10)$ rightfully notes, that "it is not those different scales separately but their combination and imbrication that created unique conditions, with unique opportunities and challenges, for lives and activisms of [local LGBT people]." As such, this article analyses how the specific combination of international and national LGBT politics as part of the European integration process has contributed to the reconfiguration of Belgrade Pride's politics.

Taking this into account, it is important to note at this point that whilst the EU may indeed have come to use Pride parades as a litmus test for the Europeanness (see e.g. Slootmaeckers and Touquet 2016), these events are not imposed on candidate countries per se. In fact, they only seem to enter the international agenda after local actors express an interest in organising it. Pride, then, is not a foreign-imposed event, but neither is it devoid of an international dimension. Pride events across the world remain deeply embedded in the history of 'Western Pride' as well as their current imagery. Acknowledging this reality, as well as the domestic origin of the desire to organise Pride, Pride is considered to be a local, yet vernacularised version of a globalised event (Thoreson 2014). Hence, one should not study how the EU enforces LGBT Pride on candidate countries, but rather examine how European pink-testing using Pride affects the domestic politics of Pride by reinscribing the international character of a practice that was previously vernacularised. 


\section{How Belgrade Pride Became a Litmus Test for Serbia's Europeanness}

Due to the limitation of space, a complete year-by-year analysis of the history of the Belgrade Pride is beyond the scope of this article. Nevertheless, based on such analysis presented elsewhere (see Slootmaeckers 2016), we can summarise its history into three distinct phases, which are each characterised by different configuration of domestic and international politics (see figure 1). Indeed, the data has indicated that throughout its history, Belgrade Pride has been subject to political calculations, both at the domestic and international levels. Whilst domestically, politicians made decisions on Pride based on their attempts to balance nationalist politics and Serbia's EU aspirations, at the European scale, the EU reaction was determined by its need to offset regional stability and security with the promotion of human rights.

\section{[insert Figure 1 around here]}

During the first period of the history of Belgrade Pride, 2001-2009, Pride did not happen due to the strong presence of nationalism in Serbian politics and the inexperience of both organisers and state. The 2001 Pride was attacked by a thousand-strong crowd, for which neither organisers nor police were prepared. In the following years, the Kosovo issue and EU conditionality related to the International Criminal Tribunal for the former Yugoslavia (ICTY) caused a resurgence of nationalism in Serbia, which in turn stopped any further attempt to organise Pride. It was only after the election of a pro-EU government and the adoption of the anti-discrimination legislation that activists thought it would be possible to organise Belgrade Pride again. Whereas activists framed the Pride as a political protest, they also strategically linked it to Serbia's EU accession process. As such, the 2009 Pride was widely perceived, both domestically and internationally, as an important test of Serbia's 
maturity and its modernisation, as well the first real test of Serbia's commitment to and the implementation of the newly adopted anti-discrimination law. However, activists overestimated the pro-EU character of the government. Although rhetorically trapped into supporting Pride, the government played on the inexperience of the organisers to bully them into cancelling the event (see Ejdus and Božović 2016). The 2009 Pride eventually was relocated by the government to the periphery of the city, in an attempt to balance the need to have the event with the wishes of the nationalist opposition against LGBT-visibility. This move, however, backfired on the government as both activists and international observers interpreted the relocation as an outright ban of the Pride, which in turn placed the Pride in the spotlight of the EU. Despite the fact that the official response in the EU's Progress Report was rather mild, the behind-the-scenes pressure was to such an extent that Serbia's EU accession process became linked to the organisation of the Belgrade Pride.

This growing importance of the EU accession process as a factor in the state's calculations on the Belgrade Pride characterises the second phase of the Pride's history (2010-2013). For example, with the Council of the European Union's decision on Serbia's application for EU membership expected in fall 2010, supporting the 2010 Belgrade Pride became an important avenue for the Serbian government to showcase Serbia's Europeanness (Mikuš 2011). As such, the 2010 Belgrade Pride was from the onset closely intertwined with Serbia's EU accession process. On the one hand, EU support for the event was formalised when Vincent Degert, then head of the EU Delegation to Serbia, signed a petition to support the 2010 Belgrade Pride (Gay Straight Alliance 2011). The Serbian government, on the other hand, also linked the Pride discursively to the EU integration process, as political leaders publicly expressed their support for Pride by explicitly linking it to the EU's values. In fact, the government used the Pride so as to demonstrate its pro-EU credentials by seemingly coorganising of the event. However, while the government indeed provided the conditions for 
Pride to happen, it did not take any preventative measures to stop the anti-gay riots that followed 2010 Pride from happening (Ejdus and Božović 2016).

The outburst of extreme violence was in the following years used by the government to engage in what can only be described as a securitisation process of the Pride, in which Pride was portrayed as an event that threatened Serbia's national security. In the following three years, the state used the riots and security threats as an excuse to - in the words of a government official — "postpone" dealing with Pride, whilst focussing on other more important sensitive issues (e.g. Kosovo) and elections. This process and the three consecutive bans of the Belgrade Pride were, in part, made possible by the EU's inconsistent pressure on Serbia. Indeed, whereas the EU considered the 2010 Pride a breakthrough in Serbia's respect for human rights, the EU did not forcefully react to the Pride bans. In fact, following the rising tension between Serbia and Kosovo (with outbursts of violence in the summer of 2011), the EU decided to prioritise regional stability over fundamental rights. As an EU official commented:

Personally — and this is not the Commission's position — I think we [the Commission] are being soft on Serbia on some issues [including Pride] because we want them to further cooperate. We want things to go well with Kosovo. [...] It is always a political game [...], so I think we are being soft on Serbia in the technical aspects because of this whole overarching political issue that is the relationship with Kosovo. ${ }^{2}$

It was only after a landmark deal between Serbia and Kosovo was struck in March 2013 that the EU began to critique the Pride bans. Indeed, after the 2013 Pride ban, a shift in the EU's language can be observed. For the first time, the Progress Report was much more direct and critical in its analysis of the Pride ban, highlighting "concerns regarding the lack of sufficient political support for the protection of the rights of LGBTI population" (European

\footnotetext{
${ }^{1}$ Interview with an anonymous official from Ministry without Portfolio responsible for EU Integration, 12 November 2015, London/Belgrade, mail interview.

2 Interview with an anonymous official from European Commission (DG Enlargement), 6 March 2014, Brussels, face-to-face interview.
} 
Commission 2013, 45). Whilst this explicit reference to the lack of political will might reflect a more coordinated approach to LGBT rights in the accession process, the EU did not follow through on the recent prioritisation of LGBT rights within the fundamental rights conditionality with concrete actions. Indeed, already back in June 2013, the EU decided to open the EU accession negotiations with Serbia conditioned on the implementation of the Brussels Agreements. In December 2013, the EU rewarded Serbia for its progress in reforming and efforts in improving its relations with Kosovo by setting a date for the start of the negations (Deutsche Welle 2013).

Nevertheless, this change of EU's tone marks the beginning of a new phase in the history of the Belgrade Pride. Contrary to the previous years, the 2014 Pride received much more political support. With the EU explicitly criticising the lack of political will to maintain Pride, and Serbia at the verge of opening the accession negotiations, the Serbian government had come to realise that maintaining the Belgrade Pride in 2014 would be considered a major litmus test for Serbia's readiness for opening chapters. As such, the government perceived banning the Pride as an unnecessary risk to Serbia's progress in the EU accession process. Indeed, as two representatives of the Ministry of Foreign Affairs explained in an interview, the EU had informally made clear that securing the Pride was seen as a condition for Serbia's advancement in the European integration process; i.e., Pride had become a litmus test for Serbia's Europeanness. Consequently, the diplomats continued, the "EU had forced Serbia's hand to have Pride," disregarding the strong opinion amongst the government that the political reality was not opportune to have Pride. ${ }^{3}$ As such, the Minister of European Integration decided to get involved in the organisation of the Belgrade Pride, in order to avoid undue delays in Serbia's accession process, and the Belgrade Pride returned without

\footnotetext{
${ }^{3}$ Interview with anonymous officials from Ministry of Foreign Affairs of the Republic of Serbia, 23 April 2015 , Belgrade, face-to-face interview.
} 
major incidents.

To summarise the history of the Belgrade Pride, it can be said that Pride has been predominantly a product of domestic politics, which in interaction with the international politics of Pride have produced the political possibilities of both the bans and the successful events. The next section of the article analyses how the politics of Belgrade Pride have been transformed throughout history as a consequence of its specific transnational politics.

\section{The Belgrade 'Ghost' Pride as a Pathology of European Pressure}

Although the return of Belgrade Pride in 2014 was able to force the topic of LGBT issues into the public debate and forced the state authorities to recognise the presence of LGBT lives, these achievements have been partly hollowed out as a consequence of the transnational politics of the event and the homocolonialist process of triangulating of EU's sexual exceptionalism through the promotion of and resistance to LGBT equality. I will discuss this process in two subsections. Whereas the first part focuses on the internationalisation and the local decoupling of Pride, the second section discusses the cooptation of pride and the militarisation of pride. Although these four sub-processes are discussed separately, it is important to note that they are dynamic, interlinked and mutually reinforcing.

\section{Internationalisation and local decoupling of pride}

Already from the initial attempt, the Belgrade Pride has always been shaped by the international visibility of LGBT politics. For example, whilst the aim of the first Pride attempt in 2001 was to take a stand against the political and societal homophobia fostered by nationalist politics of the 1990s, it remains questionable whether it was indeed able to do to 
so. Organised by a small (and arguably an elite) group of activists, the 2001 Pride enjoyed little support of a grassroots 'community'4 and seemed rather detached from Serbian LGBT people and their grievances. One long-term activist noted that the 2001 Pride was not known by the 'community' nor by friendly civil society organisations. He highlighted that "the information about the first Pride was not public; it circulated between relatively few people." 5 Hence, although some interpret the 2001 Pride as a symbolic coming out of LGBT issues in Serbia (Rhodes-Kubiak 2015, 124), what type of LGBT issues actually became visible might have been less localised than organisers had hoped for. Despite the fact that activists only cautiously invoked Europe as a reference point, opponents relied strongly on the international context, actively drawing attention to the readily available sexualised imagery of 'Western' Prides to take a stance against, what they called, the "spreading of unchristian immorality and perverse orgies" (in Djuric 2001). For example, one extremist opponent stated in a televised interview "This is not Berlin or Paris. This is Serbia. This kind of things does not happen here $[\ldots]$ these faggots, homosexuals and all that is going on against the Serbian people" (quoted in Bilic 2016b, 121). As such, the 2001 Pride was unable to create visibility of local LGBT people and their problems, and instead increased the visibility of that what it sought to challenge: the image of a 'globalised gay identity', that what opponents labelled 'homosexualism,' i.e., the idea that LGBT visibility and the Belgrade Pride are part of a Western attempt to destroy Serbian values.

When it re-emerged in 2009, Belgrade Pride was once again caught in a similar dynamic of internationalisation and local decoupling. First, whereas LGBT issues remained rather nonlocal after the 2001 Pride, the controversy associated with the adoption of the anti-

\footnotetext{
${ }^{4}$ The usage of the term community does not reflect the on the ground reality in Serbia — as an LGBT (political) community does not seem to exist. The term here should be read in relation to Pride's Western origin which was rooted in an LGBT community that together rose up against oppression.

${ }^{5}$ Interview with Miloš Urošević, Women in Black, 14 September 2015, Belgrade, face-to-face interview.
} 
discrimination law further cemented LGBT issues as an international topic. Indeed, both sides of the argument used a European argument to gain political support for or against the law: LGBT rights advocates relied heavily on EU (visa liberalisation) conditionality, while opponents framed the law as a (Western) attack on Serbian values. Despite the controversy associated with it, the 'success' of the European framing of the anti-discrimination law seemingly inspired both domestic and international actors to link the Belgrade Pride to the anti-discrimination law — as a first real test of the law. As such, maintaining the Pride became coupled to Serbia's path to the EU; a testament of Serbia's Europeanness. For example, Michael Cashman (Co-President of the European Parliament's Intergroup on LGBT Rights) stated after the 2009 Pride ban that "Serbia [had] shown that it is not ready to become a member of the EU" (quoted in Wockner 2009). Similarly, in 2010, Western/European embassies considered the 'successful' Belgrade Pride an "example of [Serbia's] embrace of Western, liberal values" (cited in Kirchick 2010). However, the externalisation of the Pride by prominent politicians as well as the EU's use of Pride as a litmus test in response to the 2009 Pride ban reinforced the delocalised visibility of Pride, ${ }^{6}$ as local LGBT lived experiences remain invisible.

Consider, for example, the media reporting on the Belgrade Pride which has arguably contributed to the invisibility of local LGBT lives in two ways. First, whilst most articles on LGBT issues are published during the period leading up to and immediately following Belgrade Pride, coverage throughout the year increases the visibility of a globalised gay identity through its predominant reproduction of foreign LGBT news. Second, the reporting on the Belgrade Pride parade itself focused almost exclusively on the state response to security issues surrounding the Belgrade Pride, thereby "effectively stifling all other

\footnotetext{
6 This observation is in line with previous scholarship. For example, Bilić (2016b) has argued that Pride in Serbia is a reflection of the globalisation of gay identity, whilst Mikuš (2011) also highlighted how the 2010 Pride Parade had a remarkable international, if not European, character.
} 
discussion around the [...] discrimination faced by members of LGBT communities and what can be done to counter it" (Igrutinović 2015, 63). Local LGBT lives, thus, are rendered invisible.

The internationalisation and linkage of Pride with a 'globalised gay identity,' together with the lack of creating meaningful visibility of LGBT people's lived experiences, arguably meant that the Belgrade Pride also lost its potential to engender an LGBT community in Serbia, as it has not (yet) been able to display a sense of mass solidarity that empowers others to come out (see Weeks 2015). Considering the imagery of the three successful Pride parades, it becomes clear that the "magical emotional impact" (Armstrong and Crage 2006, 472) Prides are said to have never occurred. On the contrary, unable to create an inviting and supportive environment, the imagery of Pride rather aided the reproduction of violence and state oppression. To illustrate, in 2009, Belgrade was covered by graffiti threatening the Pride and LGBT people more generally (slogans included: We Are Waiting for You, and Death to Homosexuals). Whilst these threats remained present during the 2010 Pride, the bloodshed during the riots exemplified how real these threats are. Although such incidents did not occur in 2014 and 2015, the high level of securitisation — Pride only made possible through the deployment of an estimated 7,000 policemen in riot gear and armoured vehicles — arguably reinforced the idea that LGBT people are not safe in Serbia unless protected by police. Indeed, pictures of the 2014 and 2015 Pride demonstrate how the Pride took place in a 'security bubble,' invisible for passers-by and impossible to join.

More generally, it has been said that the increased framing of the Belgrade Pride as a litmus test for Serbia's Europeanness by both domestic and international actors has put LGBT people at a greater risk of violence during the Pride parade period, without providing any sense of community and/or support. Indeed, as reported by the head of the community policing department during an interview, there is a yearly spike in hate crimes against LGBT 
people in the period leading up to and following the Pride. The lack of without meaningful visibility of lived LGBT experiences, the persistent securitisation of the Pride combined with the discursive and visual linkage with violence, has been identified as the main reason for the growing disconnect between activists and the people they claim to represent, with LGBT people withdrawing from the idea of Pride. ${ }^{7}$ In fact, most participants of the 2010, 2014, and 2015 Prides were predominantly international delegates — from international institutions and international human and LGBT rights civil society -, local civil society, political representatives and straight allies; local LGBT people remained a minority. Aleksandar Prica, an activist from outside Belgrade, eloquently explains the disconnect between Pride and the local LGBT population:

Generally, LGBT persons have much more problems during the Pride and during the time when Pride is being organised than during the entire year [...]. When the Pride is cancelled, a message is sent to the LGBT people that the state cannot protect them. LGBT people [...] simply don't want Pride. $^{8}$

Not only has the local LGBT population withdrawn from the Belgrade Pride, but the reverse process can also be observed. Indeed, the complicated history of the Pride has pushed Pride organisers away from engaging with LGBT people. Whilst Belgrade Pride has always had an elitist character — or as Boban Stojanović, a key Pride organiser, admits: "[Pride] does not come from the need of the community. It comes from some exclusive knowledge of individuals" -, 9 this only intensified when the organisation of Pride became fraught with uncertainty and bans. In order to have Pride, organisers reportedly spend over 90 percent of their time in communication with state representatives and the international community, with little resources left to engage LGBT people. By doing so, the already weak link with the 'community' was further severed, as “only the activist circles [seem to] know the point of

\footnotetext{
${ }^{7}$ For a more detailed study on why LGBT people have withdrawn from the Belgrade Pride, see Stojčić (2014).

${ }^{8}$ Interview with Aleksandar Prica, Asocijacija DUGA, 30 April 2015, Šabac, face-to-face interview.

${ }^{9}$ Interview with Slobodan (Boban) Stojanović, Belgrade Pride, 23 September 2015, Belgrade, face-to-face interview.
} 
Pride. LGBT people do not [know] because nobody is practically working with them on that issue, to explain what is the Pride and why Pride matters." ${ }^{10}$ Indeed, Boban Stojanović concurs:

Our idea was to have the community more involved, but with the banning [of Pride] it was not a priority. The Pride bans brought something new: to have Pride as a form, as an event. [With the bans in] 2011, 2012, and 2013 [...] there was not much space for community work. [...] You can have a campaign in which you explain what you want, why [Pride] is important, etc., but in those several years, it was almost impossible [...] because there is this other, bigger discussion: Pride, yes or no? Pride, safe or not? Pride, ban or not? ${ }^{11}$

Although non-organising activists recognise these political conditions created by the bans, they nevertheless seem to hold Pride organisers partly responsible for the disconnect with the LGBT population, especially highlighting their poor communication with the 'community' and activist scene. As one activist eloquently describes:

They [Pride organisers] need to talk to the community more. They need a link with the community. [...] [they] need to have some point where people can connect with, and that is the problem with Pride. If [good communication] is there, it will happen, but I have no idea what is happening. As part of the community, as an activist and part of the community, I have no idea what is happening [in the Pride week and with the parade]. ${ }^{12}$

Another often mentioned reason for the disconnect between Pride organisers and the wider 'community' is the discursive shift towards a (human) rights-based framing, which made Pride a goal rather than a tool. Indeed, whereas the 2009 Pride was framed as "a political protest, a procession in which one marginalised group in society [...] becomes visible and contributes to the respect for human rights" (Dragana Vučković quoted in Beta 2009), the cancellation/ban of that Pride firmly positioned the Belgrade Pride within the human rights discourse. Faced with the impossibility of having Pride, organisers indicated that, from 2010 onwards, they were increasingly framed the Pride as the expression of LGBT people's

\footnotetext{
${ }^{10}$ Interview with Aleksandar Prica, Asocijacija DUGA, 30 April 2015, Sabac, face-to-face interview.

11 Interview with Slobodan (Boban) Stojanović, Belgrade Pride, 23 September 2015, Belgrade, face-to-face interview.

${ }^{12}$ Interview with anonymous activist from Gayten-LGBT, 18 May 2015, Belgrade, face-to-face interview.
} 
(constitutional and human) right to freedom of assembly. The international attention for Pride only strengthened that shift, as the international community responded to the Pride bans by reminding Serbia of its responsibility to guarantee the exercise of freedom of assembly. Indeed, for the EU, Pride is a "question of freedom of expression, [and] freedom of assembly." 13 In fact, as there is no EU standard on Pride parades (i.e., not all Member States have Pride events), the only way in which the EU can pressure Serbia to maintain the Pride parade is by emphasising freedom of assembly. With activists perceiving European arguments the only successful approach to the Serbian government, Pride organisers were further encouraged to align themselves with the international human rights frame and made Pride, as many attest, a goal in itself. Moreover, the human rights framework remained rather unchallenged as 'successful' Prides are considered progress, with neither organisers nor international community asking more critical questions about the quality of Pride and how it contributes to improving lived experiences of local LGBT people. In fact, some activists have argued that the almost exclusive focus of the EU on Pride has seemingly given the impression the LGBT lives are reducible to this one event. In her critical blog post, queer activist Lazara Marinković (2015 original emphasis) highlights the problematic of the international overemphasising of the successfulness of Pride:

we can conclude that Belgrade Pride March 2014 didn't bring any positive social change at all. [...] Further more [sic], Serbia's example of Belgrade Pride Parade was used in the OSCE/ODIHR conference on freedom of assembly as an example of good practice, disregarding the overall status of the LGBT people and freedom of assembly in Serbia, which [are] both deteriorating.

\section{The Co-optation and Militarisation of Pride}

The detachment from the people Pride claims to represent as well as its 'litmus test-isation' raises important questions about the ownership of Pride; as Marko Karadžić suggests:

\footnotetext{
${ }^{13}$ Interview with an anonymous official from European Commission (DG Enlargement), 30 July 2013, Brussels, face-to-face interview.
} 
What I really dislike about the policy coming from the European Union is that the [progress] reports are praising the events which are not actually a step forward. [...] the message that has to be communicated after the Pride, I believe, has to be different from the one that we have. First of all, we do not have one. The messages sent after the 2010 Pride and even the last one [2014] were: "The state and politicians are not against us [LGBT people], because the EU pressures [Serbia] for these 'faggots' to get together," and then "it is a huge step because we had [Pride]", but the question one should ask is: "who had it [Pride]? A few NGO activists, the EU ambassadors and 5,000 policemen, in order to write a good report so that the EU can tell that there is good progress in Serbia?"14 (emphasis added)

Karadžić's question of 'who had Pride?' is indeed a critical issue to consider. If Pride is not for and/or by LGBT people, then for whom and by whom is the Pride organised, and why? Although it is undeniable that the organisation of Pride in Serbia has forced (some) state institutions - especially the police - to recognise LGBT people as citizens, the same cannot necessarily be said about the Serbian government. Increasing EU pressure may have "forced the government's hand" to deal with Pride, ${ }^{15}$ but the inconsistency of this pressure, combined with the earlier described 'hollowing out' of Pride as an activist tool, allowed for the transformation of Pride. There is a strong consensus amongst activists — Pride organisers and non-organisers alike - that politicians have co-opted Pride as their political tool. The first signs of such political appropriation already emerged during the organisation process of the 2010 Pride, now commonly referred to as the 'State Pride' (Mikuš 2011). Indeed, as the government came to realise that a 'successful' 2010 Pride would demonstrate Serbia's commitment to the EU integration project, the state became actively involved in organising Pride. Whilst organisers took advantage of this situation to have Pride, others feared that this political alliance would come at a steep price. Indeed, as one long-term feminist activist noted in a discussion on the 2010 Pride:

It seems to me that the Socialist Party of Serbia and the Serbian Progressive Party are planning to hijack our forms, render them meaningless, empty them from their political content... and then simply throw them away... the sole purpose of all of this is meeting "the standards" [European

\footnotetext{
${ }^{14}$ Interview with Marko Karadžić, Former State Secretary of the Minister for Human and Minority Rights, 29 April 2015, Belgrade/DC, Skype interview.

${ }^{15}$ Interview with anonymous officials from Ministry of Foreign Affairs of the Republic of Serbia, 23 April 2015, Belgrade, face-to-face interview.
} 
Union conditions]... this has nothing to do with our needs, but it is something which is asked from them... they are asked for Kosovo and they are asked for this (Pride). (quoted in Bilić 2016b, 135)

In the years to follow, this fear seemed to be well-founded as the state-condoned violence ${ }^{16}$ that accompanied the 2010 Pride provided politicians with the perfect excuse to withdraw their public support for LGBT equality and the Pride in particular. Politicians were quick to blame the LGBT activists' provocative Pride and the EU pressure for the destruction of Belgrade (see Slootmaeckers 2016). Moreover, as the international community — particularly the EU - strategically decided to focus on the success of the Pride and congratulated the state for maintaining the event, a message was sent to politicians that Pride could be strategically used as a pragmatic 'homonationalist tool' with the aim to formally fulfil the EU's accession conditions.

An additional benefit of the riots for the government was that it provided an excuse to push the LGBT issues off the political agenda. Indeed, in a period of political instability in which organising Pride would be too costly, the government used security reasons as a pretext to ban the Pride, thereby 'postponing' dealing with Pride until the (new) government sufficiently consolidated its power. Until the latter happened, it was more beneficial for the government to ban the Pride. Indeed, Perunović $(2015,82)$ convincingly argued that the Pride bans were an opportunity for the Serbian government to exercise its sovereignty with the goal to reinforce its power position "under the guise of its protective role (paradoxically impotent and omnipotent at the same time)." By banning the Pride as well as by focusing on its security aspects, the government further pushed the Belgrade Pride into the human rights

\footnotetext{
16 The riots can be described as state-condoned as the police efforts to prevent the riots were rather limited. In the name of police impartiality, opponents of the Pride were given ample opportunities to protest against the Pride and organise for the riots.
} 
frame, and thereby, albeit unintentionally, depoliticised the Pride as an activist tool. ${ }^{17}$ Thus, the Pride bans contributed to a transfer of ownership over the Pride: from LGBT activists to the state. ${ }^{18}$ As such, it can be argued that "Pride is [no longer] organised by civil society organisations, but by politicians, ${ }^{19}$ or as activists critically observe:

Pride as Pride is insignificant; it is not important. But it is a tool for political parties for their political fights. Because on the issue of Pride, you will have fights between so-called left and right; anti-EU and pro-EU: against Russia and for Russia parties. [...] You will have a clash of many people that are not LGBT on the issue of Pride, and we [LGTB people] are collateral damage. [...] It is interesting that pro and against, all those cases do not value the LGBT issue because they [politicians] are fighting their fights, they are not thinking about us; ${ }^{20}$

[As such, Pride] is just a matter of PR. The government wants to appear as having European oriented values, which I have to say is crap because it is not genuine and not sincere and that is why [Pride] happened last year [2014]. [...] It is a tool of politicians. And what I am mad about is that those organisations with the explanation that it is better to have something than nothing, they are excepting it. ${ }^{21}$

When the Pride returned to Belgrade in 2014, it was arguably again the government (particularly Vučić) that stood most to gain. Playing on the organisers' desperation to exercise their freedom of assembly, Vučić used Pride as a move to align with EU's expectations, a tool to bolster his (inter)national image as a reforming Pro-EU force and to highlight his capacity to enforce the Serbia's constitution. For example, the highly militarised imagery of the Pride is said to have helped Vučić - as personification of the state - to demonstrate that "the [state/ Vučić's government] is incontestable in its protective role and [that] its [political] will is not to be contested anymore" (Perunović 2015, 82). ${ }^{22}$ Moreover, by

\footnotetext{
17 (Then) Prime Minister Vučić's characterisation of Pride as a "leisurely walk" in 2014 perfectly illustrate this depoliticisation.

18 This transfer of ownership is further aided by the increasing conflict between LGBT organisation about the usefulness of Pride, and the what some perceive as the hegemonisation of the Pride by the current organisers, who not only have become disconnected from the LGBT people, but also from the activist community.

${ }^{19}$ Interview with Aleksandar Prica, Asocijacija DUGA, 30 April 2015, Šabac, face-to-face interview.

${ }^{20}$ Interview with Predrag Azdejković, Gay Lesbian Info Center, 02 June 2014, Belgrade, face-to-face interview.

${ }^{21}$ Interview with Igor Vojvodić, a former activist from Gay Straight Alliance, 10 May 2015, Belgrade, face-toface interview.

${ }^{22}$ This reference to the government's political will has to be read in relation to the explicit reference to the lack of political will to organise Pride in the EU's 2013 progress report.
} 
militarising the Pride, Vučić transformed the 'State Pride' into a 'Ghost Pride, ${ }^{23}$ i.e., a state tolerated manifestation of Pride which remains invisible to the wider public. ${ }^{24}$ The security perimeter — officially created to protect Pride participants — has a secondary function of a "transparent closet" (Kuhar 2011) that keeps LGBT people's visibility invisible and outside the public sphere. Apart from this physical appearance, the transparent closet also exists discursively. As already mentioned, the explicit media focus on Pride's security aspects and potential bans has contributed to the discursive invisibility of LGBT lived experiences and grievances. In other words, by securitising Pride, LGBT visibility is kept to a minimum, i.e., a ritualistic ("leisurely") walk through the city devoid of politics. Anita Mitić (Pride organiser) explains how she feels that the state and the police are

demonstrating their power much more than they are protecting us. [...] Like they are exactly isolating us and protecting us in the same way, because I feel that sometimes [with Pride and other street actions] they [the police] always come, so many of them and you are like 'is this really necessary?' You are surrounded by police, no one can pass you, and you do not have any kind of contact with the population, there is you, the circle of police and the rest of the world. ${ }^{25}$

Although the political appropriation of Pride aimed at 'closeting' the visibility politics of the event cannot be denied, the organisers' complicity in this development cannot go unnoticed. Indeed, non-organising LGBT activists and former activists have argued that as Pride developed into a goal in itself, disconnected from the 'community,' organisers' representation of Pride added to the 'closeting' of LGBT people. For example, it has been pointed out that organisers are "always explaining and elaborating very very strongly that nobody should worry, that Pride is not going to be as it is in San Francisco, that nobody is going to be naked

\footnotetext{
${ }^{23}$ Interview with Maja Mičić, YiHR - Youth Initiative for Human Rights / Former Pride Organiser, 30 October 2015, London/Belgrade, Skype interview.

${ }^{24}$ Or as Brown (2006, 98-99) writes: "the tolerance [for the gay Pride] the state urges on the citizenry is secured through our averted glance, by kind of visual privatisation that is a ghostly repetition of the actual privatisation of sexuality required if homosexuals are to be tolerated at all."

${ }^{25}$ Interview with Anita Mitić, Youth Initiative for Human Rights, 18 May 2015, Belgrade, face-to-face interview.
} 
as if that is something that should not happen," ${ }^{26}$ in an attempt to make Pride less publicly contested as well as to reduce the connection with the 'international gay identity.' By doing so, the argument goes, organisers are "trying to prepare everybody that it is going to be a very composed and controlled Pride where gay people are just going to walk," and thus reducing the possibility of LGBT people to express their lived experiences (emphasis added). ${ }^{27}$ Similarly, in 2013, Pride organisers actively decided to turn a blind eye to the homophobic comments of then Prime Minister Dačić (for the statement see Ejdus and Božović 2016, 13), as they assumed these comments were made in order to please his (nationalist) support base, whilst still allowing Pride. Indeed, talking about the 2013 Pride ban, a former Pride organiser questions whether they did not make too many compromises to make Pride happen.

I was ashamed because, in that moment, I thought we compromised a lot for the Pride to happen. We did not react so forcefully when Ivica Dačić made homophobic statements because we did not want to make a big fuss because if he allows Pride, then it is OK, and we expected Pride to happen. [...] It was a difficult pill to swallow, but I was like, 'OK, if we have Pride, then it was worth it.' We were all aware of the compromise, we were all disgusted with everything that was happening, but you wanted to try not the attack him. We also thought that that was part of his rhetoric, so he will allow the Pride since he is trying to keep the constituency covered from all angles. (emphasis added) ${ }^{28}$

Similarly, Predrag Azdejković critically observes that Pride organisers, and the activist community more generally, have become too complicit in the appropriation of LGBT issues to demonstrate Serbia's Europeanness:

It is interesting that we do not have the balls to be anti-government. If we are anti-government, next year we will not have Pride because we have Pride only when the government says so. [...] We do not need the Pride for to build a better government and better relations between the EU and the government. If we cannot be critical, and we are censoring ourselves only so that the government can say "you can have Pride," I don't see the point. It is better not to have Pride or to create that false image of Serbia being a tolerant country. No, we are not. Why are we [as activists] playing that game? $?^{29}$

\footnotetext{
${ }^{26}$ Interview with Igor Vojvodić, a former activist from Gay Straight Alliance, 10 May 2015, Belgrade, face-toface interview.

${ }^{27}$ Interview with Igor Vojvodić, a former activist from Gay Straight Alliance, 10 May 2015, Belgrade, face-toface interview.

${ }^{28}$ Interview with Maja Mičić, YiHR - Youth Initiative for Human Rights / Former Pride Organiser, 30 October 2015, London/Belgrade, Skype interview.

${ }^{29}$ Interview Predrag Azdejković, Gay Lesbian Info Center / Organiser Trans* Pride, 23 September 2015, Belgrade, face-to-face interview.
} 


\section{Conclusion}

Following Ammaturo's (2017) claim that linking LGBT rights that the appealing idea of Europe is a harmful action, this article sought to challenge the EU's practice of using Pride parades as a litmus test for Europeanness in the enlargement process (so-called pink-testing) and to analyse the political outcomes such practice produces. Introducing a transnational perspective, this article moved away from a top-down analysis in which the EU's domestic impact on LGBT rights is being evaluated towards an analysis of how to configuration of international and national politics shapes domestic LGBT politics. By doing so, the analysis aligned itself with queer scholars' call to counter the reproduction of a hegemonic Western matrix as part of the globalisation of sexual identity politics (see e.g. Ammaturo 2017; Stychin 2004). Indeed, drawing on Rahman's (2014) work on homocolonialism, this article provided a much-needed challenge to the presumed universality of Pride as a visibilityraising strategy. It does so by highlighting that embedded Prides in wider international (civilisational) politics can have serious political implications. Indeed, the findings clearly demonstrate the EU's homocolonialist practice of what Rahman $(2014,281)$ calls 'pinktesting', combined with the domestic resistance to this has had a harmful impact on local LGBT people and politics. Whereas using Pride as a litmus test for Europeanness has led to a politicisation of the issue on the international level, it also allowed for the transformation of Pride's national politics. Over the years, Belgrade Pride has been co-opted by the state to demonstrate Europeanness towards the EU, whilst the militarisation of the event created a 'Ghost Pride,' a state-tolerated manifestation of Pride which takes place in a militarised 'transparent closet' that keeps LGBT people's visibility strategies invisible and outside the public sphere, reinforcing traditional and nationalist conceptions of Serbian society. 
Moreover, the intertwining of international and domestic politics surrounding the Belgrade Pride made that LGBT activists, and Pride organisers in particular, came to occupy a rather impossible position caught between national and European politics, with limited room to escape the homocolonialist implications of the EU's pink-testing. This being the case, Serbian Pride organisers opted to align themselves with the attractive idea of Europeanness in order to allow Pride to happen as an event. Indeed, with the aim to overcome the bans but also to increase the saliency of the issue, they framed the Pride as an expression of the universal human right of freedom of assembly, linking it discursively to the European integration process. Although the internationalisation of the Pride helped to make Pride possible from 2014 onwards, this strategy also backfired as it led to the domestic depoliticisation of Pride. Increasingly decoupled from its local constituency, without sufficient support from its grassroots and with a strong reliance on the apolitical human rights discourses, Pride became a form of activism, an outcome rather than a tool to achieve change and devoid of LGBT politics.

The presented findings also have important implications for the Europeanisation of LGBT rights literature. Similar to the work of Bilić (2016a; 2016b), the article has challenged the prevailing notion that the EU accession process has been a force of good for post-Yugoslav LGBT rights and provides a more critical understanding of how the transnational LGBT politics shape LGBT politics in the region. However, the presented analysis furthers Bilić's analysis by arguing that the local disconnect of the Pride with the 'community' and the absence of a political agenda is not just due to the EU's imperial-like LGBT rights conditionality, but is also the result of the limitations in opportunities for local LGBT activisms produced by transnational character of LGBT politics. Indeed, it is argued that it was a complex feedback loop of domestic and international LGBT politics that produced critical challenges for activisms which, in turn, limited the politicality of the Belgrade Pride. 
As long as activists are caught in the liminal position between the EU and the national (within the East-West dynamic), developing a locally-grounded version of Pride might prove to be difficult, yet not necessarily impossible.

The article also raises important questions related the more general Europeanisation literature. Through the transnational analysis presented in this research, it is suggested that the EU enlargement process should be thought of as a political process where the intertwining of domestic and international politics together produces outcomes which the dominant approaches in the Europeanisation literature cannot fully explain. Indeed, rather than analysing the domestic impact of the EU in candidate countries, this article has shown that it is through the particular usage of LGBT rights within the transnational context and the interaction between domestic and international politics that the meaning of the LGBT equality norms and Pride in particular has been re-interpreted. Thus, extending the 'pathological turn' in the Europeanisation literature (see Mendelski 2016), this article has demonstrated that instrumentalisation and politicisation of reforms is not only the result of the EU's flawed outcome-focussed monitoring system, but is also a product of the particular configuration of international and national politics.

In sum, these presented findings call for a more critical analysis of the civilisational politics embedded in the EU enlargement process (but also the Eastern Partnership, for example, in relation to Kyiv Pride) — whether it be in LGBT rights or other fields — that goes beyond tracing institutional changes to include the specific transnational configurations of politics and the complexities and outcomes these produce.

\section{References}

Ammaturo, Francesca Romana. 2017. European Sexual Citizenship: Human Rights, Bodies and Identities. London: Palgrave Macmillan. 
Armstrong, Elizabeth A, and Suzanna M Crage. 2006. "Movements and Memory: The Making of the Stonewall Myth." American Sociological Review 71 (5): 724-751. Ayoub, Phillip M. 2016. When States Come Out: Europe's Sexual Minorities and the Politics of Visibility. New York: Cambridge University Press.

Beta. 2009. “"Parada Ponosa' U Beogradu Na Leto." ('Pride Parade' in Belgrade in the Summer) B92.

http://www.b92.net/info/vesti/index.php?yyyy=2009\&mm=04\&dd=28\&nav_category=1 2\&nav_id=357862.

Bilić, Bojan. 2016a. "Whose Pride? LGBT 'Community' and the Organization of Pride Parades in Serbia." In The EU Enlargement and Gay Politics: the Impact of Eastern Enlargement on Rights, Activism and Prejudice, edited by Koen Slootmaeckers, Heleen Touquet, and Peter Vermeersch, 203-220. London: Palgrave Macmillan.

Bilić, Bojan. 2016b. "Europe Gays? Europeanisation and Pride Parades in Serbia." In LGBT Activism and Europeanisation in the Post-Yugoslav Space: on the Rainbow Way to Europe, edited by Bojan Bilić, 117-153. London: Palgrave Macmillan.

Bilić, Bojan, ed. 2016c. LGBT Activism and Europeanisation in the Post-Yugoslav Space: on the Rainbow Way to Europe. London: Palgrave Macmillan.

Brown, Wendy. 2006. Regulating Aversion: Tolerance in the Age of Identity and Empire. Princeton: Princeton University Press.

Bull, Hedley. 1977. The Anarchical Society: a Study of Order in World Politics. London: Palgrave Macmillan.

Buzan, Barry. 2014. “The 'Standard of Civilisation' as an English School Concept." Millennium - Journal of International Studies 42 (3): 576-594.

Deutsche Welle. 2013. "EU Sets Date for Serbia Membership Talks.” Deutsche Welle, December 18. http://www.dw.com/en/eu-sets-date-for-serbia-membership-talks/a17304630.

Diez, Thomas. 2013. "Normative power as hegemony." Cooperation and Conflict 48 (2): 194-210.

Djuric, Milan. 2001. "Under Attack in Yugoslavia: Gay Rights, Democracy." The Gully, July 23. http://www.thegully.com/essays/gaymundo/010723yu_gay_djuric.html.

Donnelly, Jack. 1998. "Human Rights: a New Standard of Civilization?" International Affairs 74 (1): 1-23.

Ejdus, F, and M Božović. 2016. "Europeanisation and Indirect Resistance: Serbian Police and Pride Parades." The International Journal of Human Rights. (online first)

European Commission. 2009. Serbia 2009 Progress Report. Brussels: European Commission.

European Commission. 2013. Serbia 2013 Progress Report. Brussels: European Commission.

Füle, Stefan. 2014. "Statement of Commissioner Füle on Belgrade Pride Parade." European Commission, September 28. http://europa.eu/rapid/press-release_STATEMENT-14289_en.htm

Gay Straight Alliance. 2011. Step by Step: Report on Human Rights Status of LGBT Persons in Serbia 2010. Belgrade: Gay Straight Alliance.

Igrutinović, Danica. 2015. "Tanks, Truncheons, Testosterone: A Panicky Reconstruction of Masculinity in the Serbian Media After the Pride Parade." In Representation of Gender Minority Groups in Media: Serbia, Montenegro, and Macedonia, edited by Tatjana Rosic Ilić, Jasna Koteska, and Janko Ljumović, 63-80. Belgrade: Faculty of Media and Communications.

Intergroup on LGBT Rights. 2014. "LGBTI Intergroup MEP Heading to Belgrade Pride." The European Parliament Intergroup on LGBT Rights, September 26. http://www.lgbt- 
ep.eu/press-releases/lgbti-intergroup-mep-heading-to-belgrade-pride/.

Kirchick, James. 2010. "Battle in Belgrade: Is Serbia Really Ready to Join the European Union." Foreign Policy, October 11. https://foreignpolicy.com/2010/10/11/battle-inbelgrade/.

Kollman, Kelly, and Matthew Waites. 2009. "The Global Politics of Lesbian, Gay, Bisexual and Transgender Human Rights: an Introduction." Contemporary Politics 15 (1): 1-17.

Kuhar, Roman. 2011. "The Heteronormative Panopticon and the Transparent Closet of the Public Space in Slovenia." In De-Centring Western Sexualities: Central and Eastern European Perspectives, edited by Robert Kulpa and Joanna Mizielińska, 149-165. Farham, United Kingdom: Ashgate Publishing Company.

Marinković, Lazara. 2015. "At Least 2 People Beaten Up for Being Gay in Belgrade in the Last 2 Weeks.” BuzzFeed, April 17. http://www.buzzfeed.com/lazaralazara/at-least-2people-beaten-up-for-being-gay-in-belgr-6qjt.

Mendelski, Martin. 2016. "Europeanization and the Rule of Law: Towards a Pathological Turn.” Southeastern Europe 40 (3): 346-384.

Mikuš, Marek. 2011. "“'State Pride": Politics of LGBT Rights and Democratisation in "European Serbia"." East European Politics \& Societies 25 (4): 834-851.

O'Dwyer, Conor. 2012. "Does the EU Help or Hinder Gay-Rights Movements in PostCommunist Europe? the Case of Poland." East European Politics 28 (4): 332-352.

Paternotte, David, and Hakan Seckinelgin. 2015. "'Lesbian and Gay Rights Are Human Rights': Multiple Globalizations and LGBTI Activism." In The Ashgate Research Companion to Lesbian and Gay Activism, edited by David Paternotte and Manon Tremblay, 209-224. Farnham: Routledge.

Perunović, Andrea. 2015. "The State of Exception and Security Discourses: Belgrade's Pride Parades on the "No Man's Land"." In Representation of Gender Minority Groups in Media: Serbia, Montenegro, and Macedonia, edited by Tatjana Rosic Ilić, Jasna Koteska, and Janko Ljumović, 81-92. Belgrade: Faculty of Media and Communications.

Puar, Jasbir K. 2007. Terrorist Assemblages: Homonationalism in Queer Times. London: Duke University Press.

Rahman, Momin. 2014. "Queer Rights and the Triangulation of Western Exceptionalism." Journal of Human Rights 13 (3): 274-289.

Rettman, Andrew. 2010. "EU Ambassador to Attend Gay Pride in Serbia." EU Observer, October 6. https://euobserver.com/lgbti/30979.

Rhodes-Kubiak, Robert. 2015. Activist Citizenship and the LGBT Movement in Serbia: Belonging, Critical Engagement, and Transformation. New York: Palgrave.

Roth, Kenneth. 2014. "Q\&A: How to Tackle the Backlash Against Gay Rights?" World Economic Forum, October 11. https://agenda.weforum.org/2014/11/qa-how-to-tacklethe-backlash-against-gay-rights/.

Slootmaeckers, Koen. 2016. "Pride Co-Opted: Belgrade Pride as Bargaining Chip in Serbia's Europeanisation." Paper presented at UACES 46th Annual Conference. London, September 5-7.

Slootmaeckers, Koen, and Heleen Touquet. 2016. "The Co-Evolution of EU's Eastern Enlargement and LGBT Politics: an Ever Gayer Union?” In The EU Enlargement and Gay Politics: the Impact of Eastern Enlargement on Rights, Activism and Prejudice, edited by Koen Slootmaeckers, Heleen Touquet, and Peter Vermeersch, 19-44. London: Palgrave Macmillan.

Slootmaeckers, Koen, Heleen Touquet, and Peter Vermeersch, eds. 2016. The EU Enlargement and Gay Politics: the Impact of Eastern Enlargement on Rights, Activism and Prejudice. London: Palgrave Macmillan.

Stojčić, Marijana. 2014. "Summary and Final Examination.” In Parada Ponosa I LGBT 
Populacija, edited by Aleksandar Stojaković, 131-144. Belgrade: Centar za kvir studije. Stychin, Carl F. 2004. "Same-Sex Sexualities and the Globalization of Human Rights

Discourse." McGill Law Journal 49 (4): 951-968.

Szulc, Lukasz. 2018. Transnational Homosexuals in Communist Poland. London: Palgrave Macmillan.

Thoreson, Ryan R. 2014. Transnational LGBT Activism: Working for Sexual Rights Worldwide. Minneapolis, MN: University of Minnesota Press.

Weeks, Jeffrey. 2015. "Gay Liberation and Its Legacies.” In The Ashgate Research Companion to Lesbian and Gay Activism, edited by David Paternotte and Manon Tremblay, 45-57. Farnham: Routledge.

Weiss, Meredith L, and Michael J Bosia, eds. 2013. Global Homophobia: States, Movements, and the Politics of Oppression. Urbana, IL: University of Illinois Press.

Wilkinson, Cai. 2014. "Putting 'Traditional Values' Into Practice: the Rise and Contestation of Anti-Homopropaganda Laws in Russia." Journal of Human Rights 13 (3): 363-379.

Wockner, Rex. 2009. "Serbian Gay Pride Parade Cancelled After Threats.” $Q x$, September 30. http://www.qx.se/english/11794/serbian-gay-pride-parade-canceled-after-threats. 
Figure 1. Historical overview of Belgrade Pride between 2000 and 2015

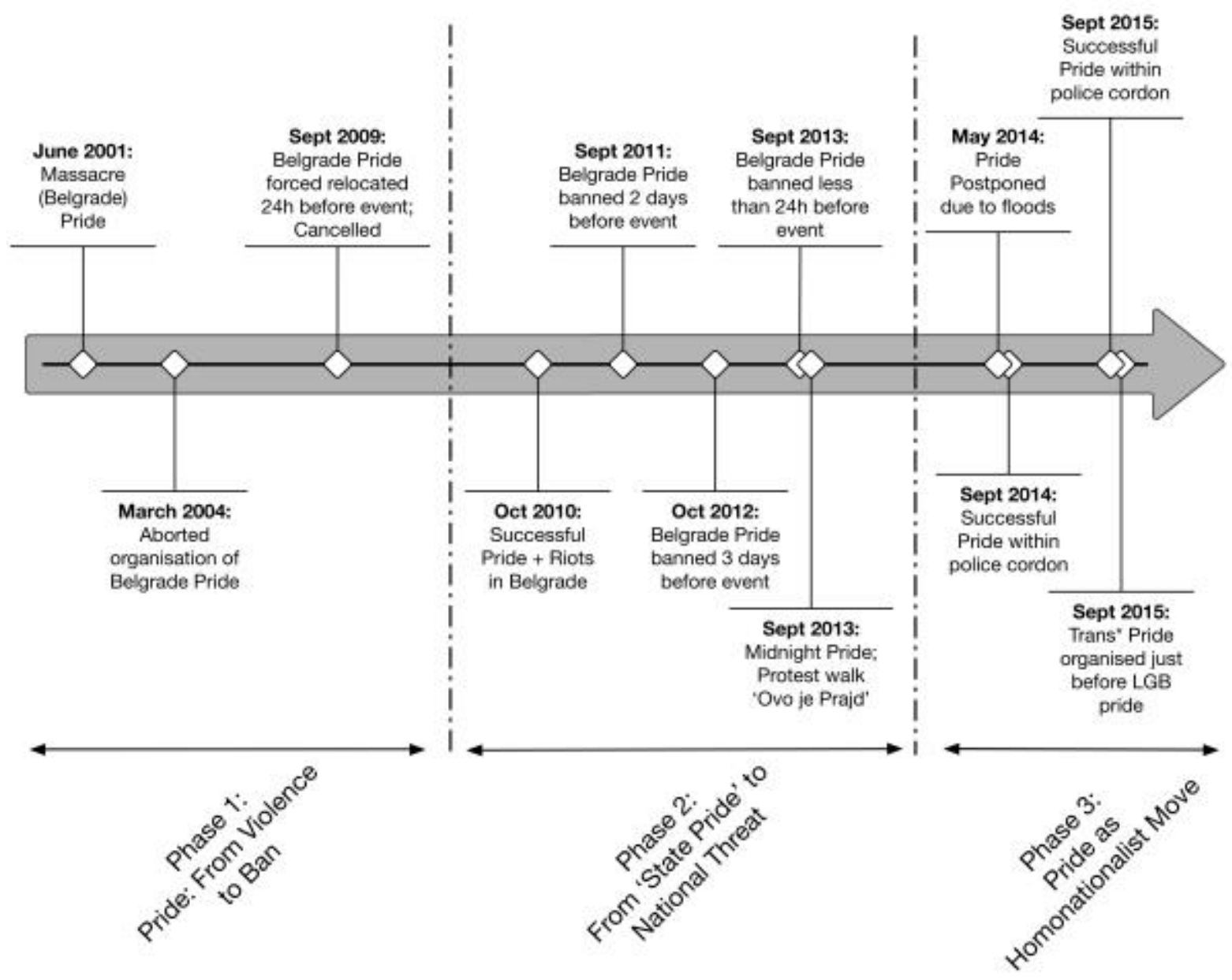

